\title{
Article \\ Advanced Exergy Analyses of a Solar Hybrid Food Dehydrator
}

\author{
Waseem Amjad 1,*(D), Muhammad Ali Raza ${ }^{1}$, Furqan Asghar ${ }^{1}$, Anjum Munir ${ }^{1}$, Faisal Mahmood ${ }^{1}$ (D), \\ Syed Nabeel Husnain ${ }^{1}$ (D), Muhammad Imtiaz Hussain ${ }^{2,3, *}$ and Jun-Tae Kim ${ }^{4, *}$
}

1 Department of Energy Systems Engineering, University of Agriculture, Faisalabad 38000, Pakistan; araza0985@gmail.com (M.A.R.); furqan.asghar@uaf.edu.pk (F.A.); anjum.munir@uaf.edu.pk (A.M.); faisal.mahmood@uaf.edu.pk (F.M.); nabeel.husnain@uaf.edu.pk (S.N.H.)

2 Agriculture and Life Sciences Research Institute Kangwon National University, Chuncheon 24341, Korea

3 Green Energy Technology Research Center, Kongju National University, Cheonan 31080, Korea

4 Department of Architectural Engineering, Kongju National University, Cheonan 31080, Korea

* Correspondence: waseem_amjad@uaf.edu.pk (W.A.); imtiaz@kangwon.ac.kr (M.I.H.); jtkim@kongju.ac.kr (J.-T.K.)

check for updates

Citation: Amjad, W.; Raza, M.A.; Asghar, F.; Munir, A.; Mahmood, F.; Husnain, S.N.; Hussain, M.I.; Kim, J.-T. Advanced Exergy Analyses of a Solar Hybrid Food Dehydrator. Energies 2022, 15, 1505. https:// doi.org/10.3390/en15041505

Academic Editors: Giorgio Vilardi, Surender Reddy Salkuti and George Kosmadakis

Received: 28 December 2021 Accepted: 14 February 2022 Published: 17 February 2022

Publisher's Note: MDPI stays neutral with regard to jurisdictional claims in published maps and institutional affiliations.

Copyright: (c) 2022 by the authors Licensee MDPI, Basel, Switzerland. This article is an open access article distributed under the terms and conditions of the Creative Commons Attribution (CC BY) license (https:// creativecommons.org/licenses/by/ $4.0 /)$.

\begin{abstract}
In this study, for the first time an advanced exergy analysis was applied to a solar hybrid food dehydrator to find out the causes of the inefficacies and to assess the actual improvement potential. The dryer was integrated with an evacuated solar tube collector and gas burner as a heating sources. Drying experiments were performed using bell pepper at $55^{\circ} \mathrm{C}$ under three heating options i.e., gas, solar and dual. The rates of exergy destructions were split into unavoidable $\left(E_{d}^{U N}\right)$ and avoidable $\left(E_{d}^{A V}\right)$ which further split into four parameters termed unavoidable endogenous $\left(E_{d}^{U N, E N}\right)$, unavoidable exogenous $\left(E_{d}^{U N, E X}\right)$, avoidable endogenous $\left(E_{d}^{A V, E X}\right)$ and avoidable exogenous $\left(E_{d}^{A V, E N}\right)$. Conventional exergy analysis revealed that drying chamber possess lower improvement potential rate (IP) than heating components while outcomes of advanced exergy analysis showed that both the design and system components interaction of heating unit imparted a major effect on its efficiency. Optimizing the operating conditions of the heating sources could reduce their higher amount of inefficiencies. The values of exergy efficiency for the overall system were calculated to be $86.66 \%, 84.18 \%, 83.74 \%$ (conventional) and $97.41 \%, 95.99 \%, 96.16 \%$ (advanced) under gas, dual and solar heating modes respectively.
\end{abstract}

Keywords: advanced exergy analysis; solar hybrid dryer; improvement potential; system optimization

\section{Introduction}

Dehydration is an energy intensive process. Inefficient use of drying medium (mostly hot air) is one of the major causes responsible for it. Secondly, lack of precise information for the kinetics of drying process is one of the main hurdles to optimize the process. Batch type food drying process is most widely used where drying medium (hot air) and its uniform circulation in the drying chamber is considered more important to encounter challenge of high energy consumption [1]. Various designs for uniform airflow distribution have been reported to decrease energy consumption. Use of inline perforation along the entire length of the drying chamber for drying uniformity has been reported [2]. Similarly, the concept of alternating airflow and swing air temperature was applied to a grain dryer to achieve drying homogeneity [3] while in another study the effect of combining hot air and microwave vacuum drying on drying uniformity of mango slices was assessed [4]. Moreover, in order to reduce energy cost, solar energy is also being widely used for food drying but it's for the small sized dryer as solar energy alone cannot process bulk quantity. Therefore, integrating existing heating sources with solar energy is of importance. Both solar photovoltaic and solar thermal (PV/T) possess wide potential for the processing of agricultural produce. Kong et al. [5] designed a food dryer using a solar PV/T collector for effective use of solar energy. Sohani et al. [6] conducted a study for the selection of best 
nanofluid type for PV/T system and it was found that $\mathrm{ZnO}$ nanofluid gave better results in term of electrical and thermal efficiencies. Regardless of the dryer type and energy resources, evaluation of process design is very important. In this regard, thermodynamic analysis especially exergetic based thermal analysis gives useful information to optimize the drying process effectively [7]. Exergy analysis helps in determining main suppliers to exergy destruction and their rearrangement in the process to improve overall thermodynamic efficiency. Aghbashlo et al. [8] presented a comprehensive review of exergy analyses of drying processes.

Energy and exergy analyses have been reported for different convective type solar food dryers like double-pass solar air dryer [9]; solar powered dryer (cabinet type) coupled with a simple solar reflector [10]; a tray dryer [11]; an indirect solar cabinet dryer [12]; a solar tunnel drying process [13]; semi-industrial continuous band dryer [14] and an indirect solar tunnel dryer [15]. Most of the reported thermal analysis are based on the type of food product used. It shows that exergy analysis of convective type hot air solar dryer has been reported widely using solar concentrator, flat plate collector, and solar tunnel but limited work has been reported using vacuum tube collector [16] with only two studies reporting use of vacuum tube collector $[17,18]$. Energy and conventional exergy analysis has been reported for a solar hybrid dryer for the assessment of dryer design under different heating modes [17]. Lamnatou et al. [18] performed thermal analysis of a simple food tray dryer coupled with solar collector. Thin layer drying models were fitted and an optimal collector size was selected. It was concluded that energy/exergy analysis provided better way to evaluate solar drying system.

In order to assess the inadequacies of the system or process, use of conventional exergy analysis is in practice but its outcomes are not being used well for the improvement of system due to lack of a formal procedure and has some barriers to show the real recoverable losses [19]. For this purpose, interactions among different system components are required to consider for which advanced exergy analysis enable to understand that how does working of each of system component depend on or effect the other component/s functionality which cannot be assessed through conventional exergy analysis due to lack of a formal procedure. Applying advanced exergy analysis, thermodynamic efficiency of the system can be improved in real sense by splitting the exergy destruction (called advanced exergy analysis) into avoidable and unavoidable parts and alternatively into endogenous and exogenous parts. The improvement potential for each system component due to existing technical possibilities can be assessed and possible measures can be done.

Being a relatively new method, applications of advanced exergy analysis in different energy related systems is low. In case of food drying, its application is very limited and as per authors current knowledge, only three studies found reporting use of advanced exergy analysis for the food drying system using heat pump, ground source heat pump and a gas engine heat pump. The concept was applied to a heat pump drying system to assess its functionality under different operating temperatures [20]. It was found that internal operating conditions were the main cause for the inefficiencies of compressor and condenser. Further in another study, thermal analysis of a ground-source heat pump (GSHP) food dryer was done by applying advanced exergy [21]. Each component of the system was considered for analysis and condenser was found more important part from design aspect. Gungor et al. [22] used a gas engine heat pump drying system to conduct thermal analyses (conventional and advanced exergy) using medicinal and aromatic plants. Avoidable and unavoidable exergy destructions were calculated for each system component and it was found that avoidable exergy destructions can be decreased by design improvements. Tinoco-Caicedo et al. [23] conducted an advanced exergy and exergoeconomic analysis of an industrial spray dryer to find out improvement potential in energy and process cost. It was found that exergoeconomic optimization can improve the overall process. No study has been found focusing on applying advanced exergy analysis in hot air food dryer integrated with solar energy for the drying of perishables agricultural produce (fruits and vegetables). Moreover, advanced exergy based thermal analysis of a batch type food 
dryer having different heating combinations is a missing part as well. Applying advanced exergy analysis in food drying process is of highly useful to understand the heat flow and distribution and based on that developing strategy for improvement. In the current study, the concept of advanced exergy analysis was applied to a solar hybrid dryer for estimating the exergy destruction of its different components; helpful to improve the system efficiency. Major system components included gas burner, solar evacuated tube collector, heat exchanger and drying chamber. Experiments were conducted under three heating sources i.e., gas heating mode, solar heating mode and dual heating mode to assess working efficiency through interactions among components. For each heating case, rates of exergy destruction were split into unavoidable and avoidable parts.

\section{Materials and Methods}

\subsection{Drying Unit Used}

A batch type food dryer integrated with an evacuated tube solar collector and a gas burner as heating sources has been used as shown in Figure 1. It has a prominent feature of inline perforation along the drying chamber for uniform airflow distribution. For solar heating, an evacuated tube collector (30-tubes) was connected with a heat exchanger (capacity $35 \mathrm{~L}$ ) through PVC pipe fitting in a closed loop having a water circulation pump $(0.5 \mathrm{~kg} / \mathrm{s}, 0.34 \mathrm{~kW})$. A radial blower fan $(1.12 \mathrm{~kW}$, Teco-Tokyo) was used for air draft. In order to run the system continuously and to compensate instability in solar intensity (in case dual/hybrid heating), a gas burner was also installed. An opening (diameter $0.125 \mathrm{~m}, 0.059 \mathrm{~m}^{3} / \mathrm{s}$ ) with a damper used to get fresh air. After heating, warm air enters into an inlet channel (rectangular) where it enters into the drying chamber through inlet perforation sheet. The drying chamber consisted of 45 food trays arranged on three trolleys (15 trays/trolley) having a gap between two consecutive trays exactly in front of perforated inlet holes to get drying uniformity. For air recirculation, another similar perforation sheet was installed opposite to inlet side of the drying chamber. An exhaust fan (variable speed, $0.34 \mathrm{~kW}$, Deutz, Köln, Germany) used at the top of drying chamber for moisture removal. The drying operation was controlled using a control box having provision of setting the drying temperature and humidity levels, auto working of single or dual heating modes and fans.

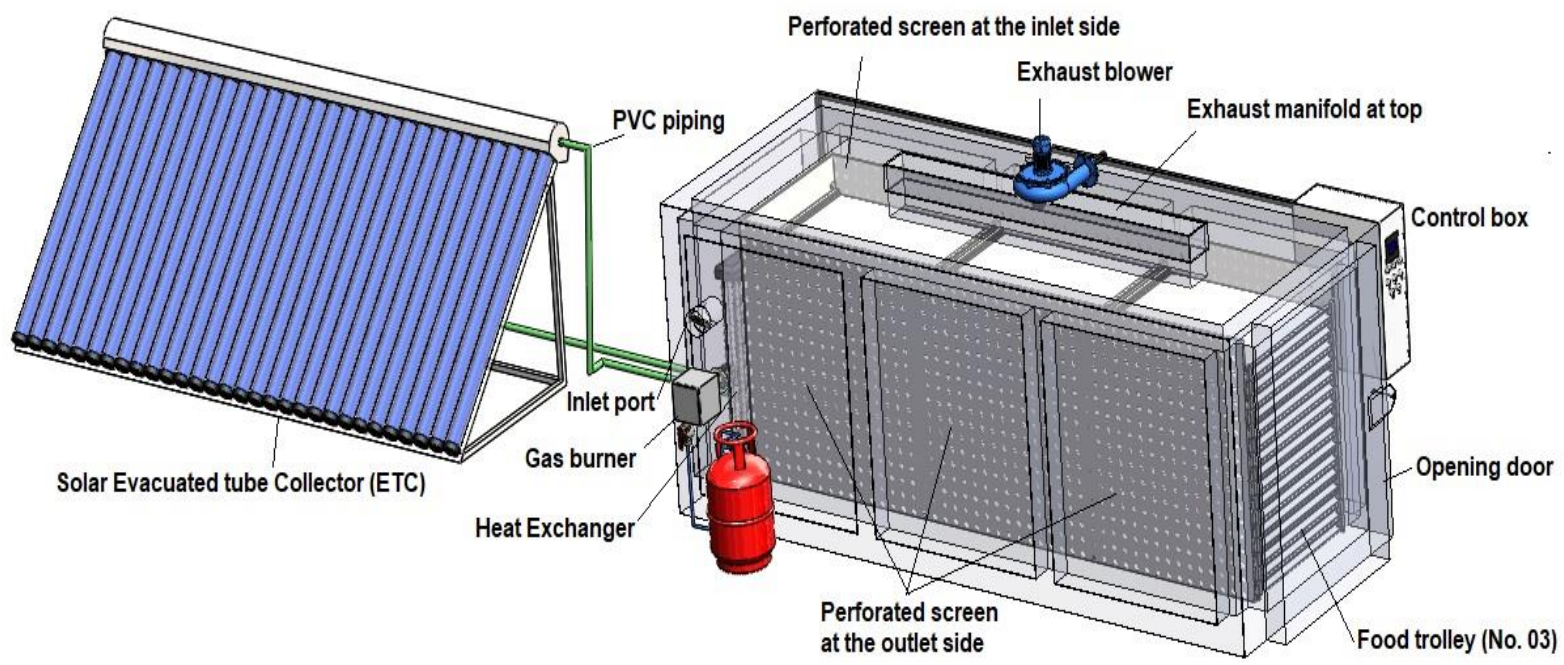

Figure 1. Solar hybrid dehydrator used in the current study [2].

\subsection{Drying Procedure and Measurements}

Fundamentals parameters are required to perform conventional exergy analysis and outcomes are used for establishing advanced exergy analysis. For this, in the current study drying experiments were performed using locally available bell pepper as drying material. As the dryer can work using solar energy as well as gas as heating source, so 
experiments were performed under three heating modes i.e., gas heating, solar heating and dual heating source. Before loading, the drying material was cut in longitudinal axis to make pieces of almost similar sizes (avg. 3.5 inches long). Although it was tried to get uniform sliced pieces but bell peppers were of different sizes in length and width so possibility of heterogeneous sample product could not be eliminated. After that drying material of $2 \mathrm{~kg}$ was put on a single tray (45 trays in total and each has an area of $0.64 \mathrm{~m}^{2}$ ). The product initial moisture content was calculated to be $81 \%$ and it was dried up to $15 \%$ moisture content. For weighting samples during drying process, a digital weight balance (SF-400) was used. Although power required for the operation of fan and water circulation pump can be supplied by installing PV system but in the current study grid electricity was used and a single phase two wire kWh-meter was used to quantify the energy used. The real time experimental setup has been shown in Figure 2.

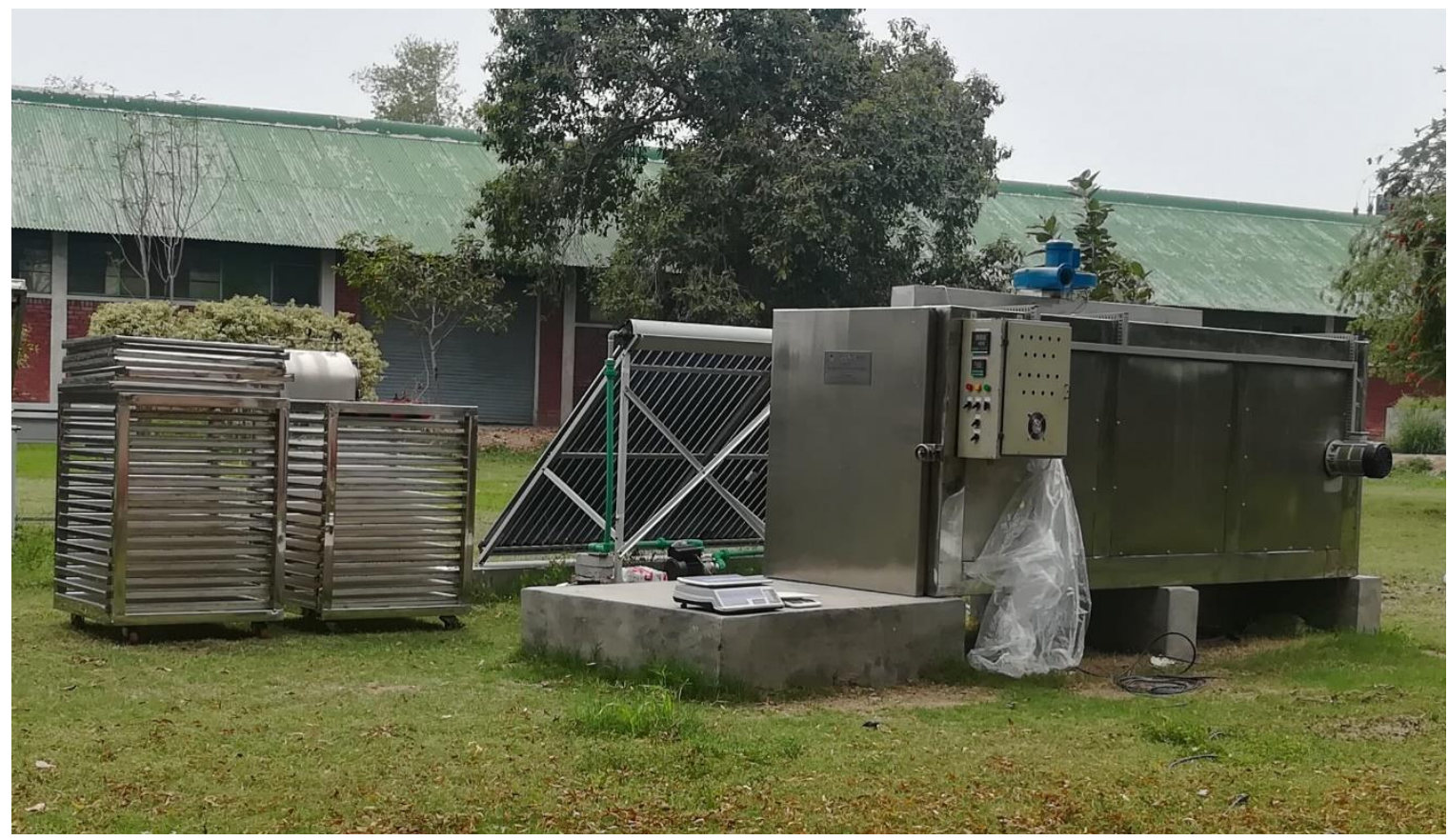

Figure 2. Real time experimental setup of solar hybrid food dehydrator.

\subsection{Exergetic Thermal Analyses}

\subsubsection{Conventional Exergy Analysis}

Mass and energy conservation principles along with exergy balance equations were used for exergy analysis under general steady flow process. This can be done for a complete system and its components level. Table 1 shows general equations used for the calculations of exergy inflow, outflow, losses and performance parameters. For this, drying air temperature at various positions in the system was measured using k-type thermocouples connected with data logger. Inlet air speed was measured using anemometer (Uni-T363). Two temperature controllers (Rex-C700) were used to measure the inlet and outlet water temperature at evacuated tube collector. 
Table 1. Equations used for the calculations of different parameters used to conduct conventional exergy analysis.

\begin{tabular}{|c|c|c|c|}
\hline Parameter & Equation & Remarks & Equation No. \\
\hline Exergy balance & $\sum \mathrm{E}_{\mathrm{Xi}_{\mathrm{i}}}=\sum \mathrm{E}_{\mathrm{Xo}_{\mathrm{o}}}+\sum \mathrm{E}_{\mathrm{Xd}_{\mathrm{d}}}$ & $\begin{array}{c}\text { Useful amount of energy }(\mathrm{kJ} / \mathrm{kg}) \text { for the air } \\
\text { entering, utilizing and outflowing in a system } \\
\text { or a subcomponent }\end{array}$ & (1) \\
\hline Exergetic rate & $\dot{\mathrm{E}}_{\mathrm{Xr}}=\mathrm{E}_{\mathrm{X}} \times \dot{\mathrm{m}}$ & Exergy flow rate & $(2)$ \\
\hline \multirow{3}{*}{ Exergy inflow and outflow } & Exergy $=c_{p}\left[\left(T_{k t h}-T_{a}\right)-T_{a} \ln \frac{T_{k t h}}{T_{a}}\right]$ & $\begin{array}{c}\text { General equation of exergy flow for a } \\
\text { respective component or positions as marked } \\
\text { in Figure } 2\left(\mathrm{~T}_{\mathrm{k}} \text { and } \mathrm{T}_{\mathrm{a}} \text { stand for temperatures }\right. \\
\text { of } \mathrm{k}_{\mathrm{th}} \text { component and ambient } \\
\text { air respectively. }\end{array}$ & (3) \\
\hline & $\mathrm{Ex}_{\mathrm{dci}}=\mathrm{c}_{\mathrm{pda}}\left[\left(\mathrm{T}_{\mathrm{dci}}-\mathrm{T}_{\mathrm{a}}\right)-\mathrm{T}_{\mathrm{a}} \ln \frac{\mathrm{T}_{\mathrm{dci}}}{\mathrm{T}_{\mathrm{a}}}\right]$ & $\begin{array}{l}\text { Exergy inflow to the drying chamber }\left(\mathrm{T}_{\mathrm{dci}}\right. \\
\text { stands for temperatures at the inlet of } \\
\text { drying chamber). }\end{array}$ & $(4)$ \\
\hline & $\mathrm{Ex}_{\mathrm{dco}}=\mathrm{c}_{\mathrm{pda}}\left[\left(\mathrm{T}_{\mathrm{dco}}-\mathrm{T}_{\mathrm{a}}\right)-\mathrm{T}_{\mathrm{a}} \ln \frac{\mathrm{T}_{\mathrm{dcc}}}{\mathrm{T}_{\mathrm{a}}}\right]$ & $\begin{array}{l}\text { Exergy outflow of the drying chamber }\left(\mathrm{T}_{\mathrm{dco}}\right. \\
\text { stands for temperatures at the outlet of } \\
\text { drying chamber). }\end{array}$ & (5) \\
\hline \multicolumn{4}{|c|}{ Performance parameters } \\
\hline Exergy efficiency & $\eta_{E x}=\frac{E_{X_{r}} 7 \& 8}{E_{X_{r} 6}+P_{\text {exhaust fan }}} \times 100$ & $\begin{array}{l}\text { It is used for drying chamber. Energy required } \\
\text { by exhaust blower is also considered. }\end{array}$ & (7) \\
\hline Improvement potential & $\mathrm{IP}=(1-\eta)\left(\mathrm{E}_{X_{i}}-E_{X_{0}}\right)$ & $\begin{array}{c}E_{X_{i}} \text { exergy inflow and } E_{X_{0}} \text { exergy outflow of } \\
\text { respective component }\end{array}$ & (8) \\
\hline Exergetic factor & $\mathrm{f}=\frac{\text { Exergy inflow at } \mathrm{k}_{\mathrm{th}} \text { component }}{\text { Total exergy inflow to the system }}=\frac{E_{\mathrm{X}_{\mathrm{i}, \mathrm{k}}}}{\mathrm{E}_{\mathrm{X}, \mathrm{tot}}} \times 100$ & $\begin{array}{c}\mathrm{E}_{\mathrm{X}, \mathrm{k}} \text { exergy inflow into } \mathrm{k}^{\text {th }} \text { component, } \mathrm{E}_{\mathrm{X}, \text { tot }} \\
\text { total exergy inflow in the system }\end{array}$ & (9) \\
\hline Relative irreversibility & $\mathrm{RI}=\frac{\mathrm{E}_{\mathrm{Xd}, \mathrm{k}}}{\mathrm{E}_{\mathrm{Xd}, \mathrm{tot}}} \times 100$ & $\begin{array}{l}\mathrm{E}_{\mathrm{Xd}, \mathrm{k}} \text { exergy destruction at } \mathrm{k}^{\text {th }} \text { component, } \mathrm{E}_{\mathrm{Xd} \text {,tot }} \\
\text { total exergy destruction in the system }\end{array}$ & $(10)$ \\
\hline Sustainability index & $\eta_{\mathrm{Ex}}=1-\frac{1}{\mathrm{SI}}$ & & $(11)$ \\
\hline
\end{tabular}


In order to conduct exergetic thermal analysis (both conventional and advanced), the entire system was divided into two components named as heating part and drying part (drying chamber). For this, Figure 3 shows schematic of complete drying system illustrating its various components and positions to divide the system into two major subcomponents i.e., drying and heating to conduct conventional and advanced exergy analyses. Based on the used heating sources (solar and gas), the heating part further categorized into three modes i.e., gas, solar and dual. Values of exergy outflow and exergy inflow were calculated using Equation (3) (Table 1) for these respective components. During conventional exergy analysis, four performance parameters (as listed in Table 1) were also calculated to investigate the performance of solar assisted dryer along with exergy efficiency. The value of improvement potential rate (IP) is helpful to assess the possible improvement in a system component under consideration. Lower IP value for a component means the difference between exergy inflow and outflow is less causing a decreased irreversibility for that component [14]. Relative irreversibility (RI) and exergetic factor $(f)$ are other performance parameters which may also be used to perform thermal analysis of system component. Fraction of exergy destruction taken placed in a component relative to total system exergy destruction is termed as relative irreversibility for that component. While exergetic factor for a system component is based on the exergy inflow to that component relative to total system exergy inflow. Additionally, keeping in view the concept and need of sustainable development, efficient use of energy sources is important in spite of using clean and affordable energy sources. So exergy analyses are helpful to improve sustainability using a term sustainability index (SI) which describe a relationship to assess the effect of exergy efficiency of a component or system on sustainability [24].

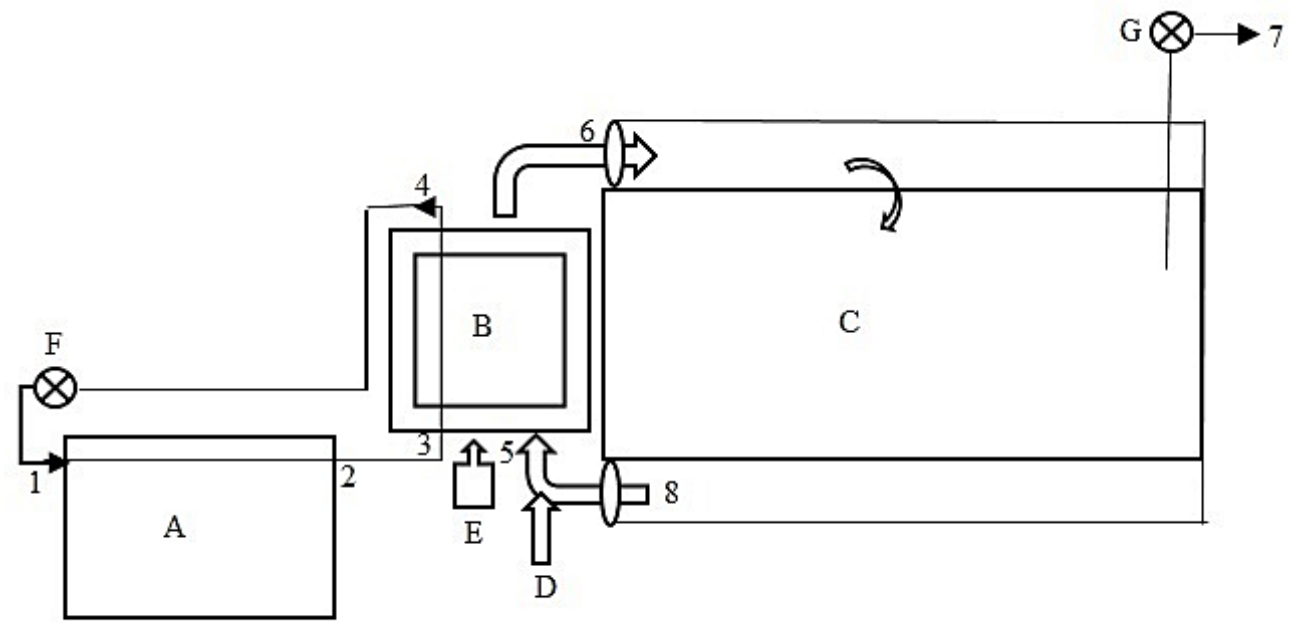

Inlet (1) and outlet (2) of solar tube collector (A)

Inlet (3) and outlet (4) of heat exchanger (B)

Air entrance (5) to heat exchanger

Air temperature at the inlet (6) of drying chamber (C)

Exhaust flow at the top of dryer (7) Air recirculation (8)

Fresh air (D) Gas burner (E) Water circulation pump (F) Exhaust blower (G)

Figure 3. Schematic illustration of different components of dryer and streams with marked points used in equations for the exergy analysis (conventional and advanced).

\subsubsection{Advanced Exergetic Analysis}

In order to perform an advanced exergy analysis, the rate of exergy destruction for a system component can be divided into parts using two splitting concepts named endogenous, exogenous and avoidable, unavoidable keeping the total exergy destruction constant for that component [19]. It provides better understanding of conventional exergy analysis enabling to improve the system [25]. 
A system is a combination of components and their working depend upon each other. For a $\mathrm{k}^{\text {th }}$ component of system (component being considered), endogenous part of total exergy destruction is estimated/calculated by taking component actual (real) operational efficiency while it is assumed that all other system components are being operated with perfect conditions i.e., no irreversibilities [22]. So in case of endogenous part, irreversibilities occur only in $\mathrm{k}^{\text {th }}$ component which illustrates the exergy destruction rate independent from the other system components. On the other hand, exogenous part of total exergy destruction for the $\mathrm{k}^{\text {th }}$ system component is caused not only because of the irreversibility occurred in the $\mathrm{k}^{\mathrm{th}}$ component but also of other components irreversibilities indicating the inefficiencies caused by the remaining components of the system. Designing a system under feasible limits would has some technical and economic limitations in design. So under such circumstances, the portion of exergy loss which cannot be avoided is termed as unavoidable part of exergy destruction. For calculation, the system component under consideration is parted from the system and optimized (favorable) operational conditions are used to calculate its unavoidable part of exergy destruction. The remaining part is termed as avoidable part of exergy destruction. The avoidable exergy destruction indicates the actual possibilities of reducing the inefficiencies (thermodynamic) of the system components [26].

These two possibilities of splitting the exergy destruction are combined to compute four valuable terms named as avoidable-exogenous (AV-EX), avoidable-endogenous (AVEN), and unavoidable-exogenous (UN-EX), unavoidable-endogenous (UN-EN) exergy destruction. The complete mechanism of splitting the exergy destruction obtained through conventional exergy analysis has been shown in Figure 4. The unavoidable endogenous is the part of exergy destruction in $\mathrm{k}^{\text {th }}$ component of system when component functions at its highest conceivable efficiency (unavoidable exergy destruction) while other components work at ideal conditions (endogenous exergy destruction) [21]. The combined cases with avoidable part of exergy loss/destruct are of most significance to determine the magnitude of inefficiencies triggered from a system component itself (avoidable-endogenous) or caused from the remaining components (avoidable-exogenous). Inefficiencies due to AV-EN part of exergy destruction can be decreased by improving the component (being considered) efficiency while inefficiencies due to AV-EX part could be decreased by increasing the efficiency of other components or structural improvements of the overall system. The equations used for the calculations of these split and combined exergy destructions along with adjusted (modified) efficiencies are presented in Table 2 [21,25].

Table 2. Equations used for the calculations of various parameters required to perform advanced exergy analysis.

\begin{tabular}{|c|c|c|}
\hline Parameters & Equation & Equation No. \\
\hline Unavoidable (UN) & $\dot{\mathrm{E}} \mathrm{x}_{\mathrm{d}, \mathrm{k}}^{\mathrm{UN}}=\dot{\mathrm{E}} \mathrm{Ex}_{\mathrm{out}, \mathrm{k}}^{\text {Real }} \times\left(\frac{\dot{\mathrm{E}} \mathrm{x}_{\mathrm{d}, \mathrm{k}}}{\dot{\mathrm{E}} \mathrm{x}_{\mathrm{out}}}\right)^{\mathrm{UN}}$ & $(12)$ \\
\hline Avoidable (AV) & $\dot{\mathrm{E}} \mathrm{x}_{\mathrm{d}, \mathrm{k}}^{\text {Real }}=\dot{\mathrm{E}} \mathrm{x}_{\mathrm{d}, \mathrm{k}}^{\mathrm{UN}}+\dot{\mathrm{E}} \mathrm{x}_{\mathrm{d}, \mathrm{k}}$ & (13) \\
\hline Endogenous (EN) & $\dot{E} x_{d, k}^{E N}=\dot{E} x_{\text {out }, \mathrm{k}}^{\text {Real }} \times\left(\frac{\dot{\mathrm{E}} \mathrm{x}_{\mathrm{d}, \mathrm{k}}}{\dot{\mathrm{E} x}}\right)^{\mathrm{EN}}$ & (14) \\
\hline Exogenous (EX) & $\dot{\mathrm{E}} \mathrm{x}_{\mathrm{d}, \mathrm{k}}^{\text {Real }}=\dot{\mathrm{E}} \mathrm{x}_{\mathrm{d}, \mathrm{k}}^{\mathrm{EN}}+\dot{\mathrm{E}} \mathrm{x}_{\mathrm{d}, \mathrm{k}}^{\mathrm{EX}}$ & (15) \\
\hline Unavoidable Endogenous (UN-EN) & $\dot{\mathrm{E}} \mathrm{x}_{\mathrm{d}, \mathrm{k}}^{\mathrm{UNEN}}=\dot{\mathrm{E}} \mathrm{x}_{\mathrm{out}, \mathrm{k}}^{\mathrm{EN}} \times\left(\frac{\dot{\mathrm{E}} \mathrm{x}_{\mathrm{d}, \mathrm{k}}}{\dot{\mathrm{E}} \mathrm{x}_{,}}\right)^{\mathrm{UN}}$ & (16) \\
\hline Unavoidable Exogenous (UN-EX) & $\dot{\mathrm{E}} \mathrm{x}_{\mathrm{d} \mathrm{k}}^{\mathrm{UN}}=\dot{\mathrm{E}} \mathrm{Ex}_{\mathrm{dk}}^{\mathrm{UNEN}}+\dot{\mathrm{E}} \mathrm{Ex}_{\mathrm{d} \mathrm{K}}^{\mathrm{UN}}$ & (17) \\
\hline Avoidable Endogenous (AV-EN) & $\dot{\mathrm{E}} \mathrm{E}_{\mathrm{d}, \mathrm{k}}=\dot{\mathrm{E}} \mathrm{x}_{\mathrm{d}, \mathrm{k}}+\dot{\mathrm{E}} x_{\mathrm{d}, \mathrm{k}}^{\mathrm{AVEN}}$ & $(18)$ \\
\hline Avoidable Exogenous (AV-EX) & 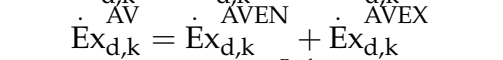 & (19) \\
\hline Efficiency & $\varepsilon_{\text {modified }}=\frac{\dot{\mathrm{Ex}}_{\mathrm{out}, \mathrm{k}}^{\text {Real }}}{\dot{\mathrm{Ex}}_{\mathrm{in}, \mathrm{k}}^{\text {Real }}-\dot{\mathrm{E}} \mathrm{Ex}_{\mathrm{d}, \mathrm{k}}-\dot{\mathrm{Ex}}_{\mathrm{d}, \mathrm{k}}^{\mathrm{AVEX}}} \times 100$ & (20) \\
\hline
\end{tabular}




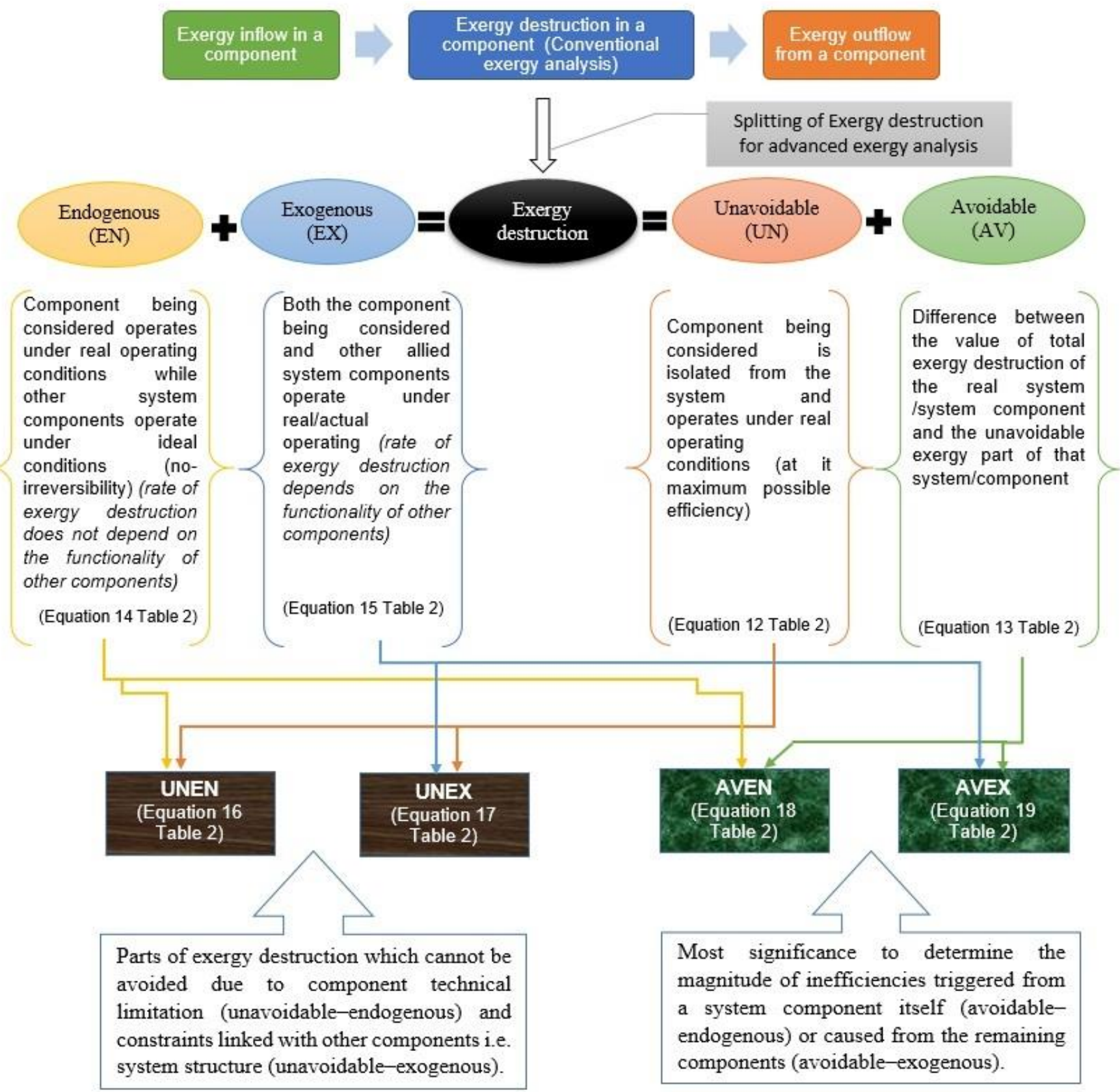

Figure 4. Flowchart of splitting the exergy destruction of conventional exergy analysis into different parts for advanced exergy analysis of solar hybrid food dehydrator.

\subsubsection{Assumptions under Theoretical and Operating Conditions}

In order to conduct advanced exergy analysis, theoretical, operating conditions i.e., unavoidable conditions are required for calculations. The conditions assumed during analysis were: no chemical reactions occurred during process, flow of heat to the system and from the system was positive. For each system component, theoretical operating conditions followed the assumption that maximum rate of heat transfer took placed (in collector, heat exchanger and drying chamber).

Outcomes of exergetic parameters (exergy inflow, outflow and destruction) calculated using theoretical operating conditions were used to determine endogenous and exogenous exergy destructions. Similarly outcomes calculated under unavoidable operating conditions used to calculate avoidable and unavoidable parts of exergy loss considering assumptions 
based on technical as well as economic limitations in the design of system component. Theoretical and operating conditions of major components are shown in Table 3.

Table 3. Assumption for calculating exergetic parameters under theoretical and operating (unavoidable) conditions.

\begin{tabular}{ccc}
\hline Component & $\begin{array}{c}\text { Theoretical/Ideal Operating } \\
\text { Conditions (without } \\
\text { Irreversibilities) }\end{array}$ & $\begin{array}{c}\text { Unavoidable/Actual } \\
\text { Operating Conditions }\end{array}$ \\
\hline Drying chamber & $\mathrm{T}=60^{\circ} \mathrm{C}, \Delta \mathrm{t}=35^{\circ} \mathrm{C}$ & $\mathrm{T}=55^{\circ} \mathrm{C}, \Delta \mathrm{t}=25^{\circ} \mathrm{C}$ \\
\hline Heat exchanger & $\begin{array}{c}\eta=79 \% \\
\mathrm{t} \text { air }=35^{\circ} \mathrm{C} \\
\Delta \mathrm{t} \text { water }=40^{\circ} \mathrm{C}\end{array}$ & $\begin{array}{c}\eta=70 \% \\
\mathrm{t} \text { air }=32{ }^{\circ} \mathrm{C} \\
\Delta \mathrm{t} \text { water }=35^{\circ} \mathrm{C}\end{array}$ \\
\hline ETC & $\eta=73 \%, \Delta \mathrm{t}=35^{\circ} \mathrm{C}$ & $\eta=64 \%, \Delta \mathrm{t}=27{ }^{\circ} \mathrm{C}$ \\
\hline Pump circulation & $\mathrm{m}=0.52 \mathrm{~kg} / \mathrm{s}$ & $\mathrm{m}=0.5 \mathrm{~kg} / \mathrm{s}$ \\
\hline Air inflow & Flow $=0.061 \mathrm{~m}^{3} / \mathrm{s}$ & $0.059 \mathrm{~m} / \mathrm{s}$ \\
\hline
\end{tabular}

\section{Results and Discussions}

\subsection{Conventional Exergy Analysis}

In order to conduct an advanced exergy analysis, the experimental results of detailed conventional exergy analysis have been summarized in Table 4. Exergy inflow, outflow and losses values, exergetic efficiency and performance parameters were calculated for three cases of drying unit based on the mode of heating options (gas, solar and dual). The results show that the heating component (in all three cases) possessed higher values of exergetic factor indicating that heating part of the system dealt major amount of system exergy. Although exergetic factor for the drying chamber was lowered than that of heating component but it also handled a significant amount of exergy in the system while possessing lower improvement potential rate (IP) than heating component i.e., $0.69 \mathrm{~kW}$ less in case I, $0.98 \mathrm{~kW}$ in case II and $1.59 \mathrm{~kW}$ in case III. It shows that amount of exergy handled effectively in the drying chamber due to uniform air distribution through inline perforation.

Table 4. Outcomes of conventional exergy analysis obtained from drying experiments.

\begin{tabular}{|c|c|c|c|c|c|c|c|c|c|}
\hline & Combination & $E_{x i}(k W)$ & $E_{x o}(k W)$ & $E_{x d}(k W)$ & $\eta_{\text {ex }}(\%)$ & f ( $\%)$ & IP (kW) & RI (\%) & SI \\
\hline \multirow{3}{*}{ Case-I } & Drying chamber & 15.73 & 13.35 & 2.38 & 84.87 & 47.91 & 0.36 & 54.34 & 6.61 \\
\hline & Gas heating & 17.10 & 15.10 & 2.00 & 47.51 & 52.09 & 1.05 & 45.66 & 1.90 \\
\hline & Overall system & 32.83 & 28.45 & 4.38 & 86.66 & 100.00 & 0.58 & 100.00 & 7.50 \\
\hline \multirow{3}{*}{ Case-II } & Drying chamber & 14.55 & 12.42 & 2.13 & 85.36 & 46.41 & 0.31 & 42.94 & 6.83 \\
\hline & Dual heating & 16.80 & 13.97 & 2.83 & 54.32 & 53.59 & 1.29 & 57.06 & 2.19 \\
\hline & Overall System & 31.35 & 26.39 & 4.96 & 84.18 & 100.00 & 0.78 & 100.00 & 6.32 \\
\hline \multirow{3}{*}{ Case-III } & Drying chamber & 12.95 & 11.10 & 1.85 & 85.71 & 45.28 & 0.26 & 39.78 & 7.00 \\
\hline & Solar heating & 15.65 & 12.85 & 2.80 & 34.10 & 54.72 & 1.85 & 60.22 & 1.52 \\
\hline & Overall system & 28.60 & 23.95 & 4.65 & 83.74 & 100.00 & 0.76 & 100.00 & 6.15 \\
\hline
\end{tabular}

Comparing the performance of heating sources, the highest IP rate $(1.85 \mathrm{~kW})$ was calculated for heating chamber using solar heating (case III) with lowest exergy efficiency $(34.10 \%)$. It could be due to the reason that solar heating source (vacuum tube collector of thirty tubes) was not enough to compensate the fluctuation in drying air temperature especially just after the loading of perishables in the drying chamber (high moisture removal rate at early stages) leading to lower sustainability index. At early stages of food drying processes, the rate of moisture removal is high due to the loosely bound surface moisture content [2]. Although, in case of gas and dual heating modes, the set drying temperature was maintained throughout the drying process causing more exergy efficiency but dual heating mode gave better efficiency as well as sustainability index. It was because of the provision of solar energy in dual heating mode, so the values of exergetic efficiency $(54.32 \%)$ 
and sustainability index (2.19) of dual heating mode were higher than that of gas heating mode. On the other side in case of gas heating mode, the improvement potential rate for the overall system is lower than other two heating options due to the undersized solar collector (based on the output of case III).

\subsection{Advanced Exergy Analyses}

The understanding of accumulated irreversibilities in the system components can be done using conventional exergy analysis but exact assessment of their resources and possible improvement potentials cannot be recognized [22]. For this, the amount of exergy destructions for a system component is split into parts to understand the causes of thermal inefficiencies which is significant to optimize overall system and this process is termed advanced exergy analysis. In this analysis, impact of component interactions, technical design and operational constraints on the system performance and its improvement potential are estimated [20]. For advanced exergy analysis, at first, rate of exergy inflow, outflow and losses were calculated for three cases (same as in conventional exergy analysis) under theoretical and experimental (for unavoidable calculations) drying process conditions and outcomes are tabulated in Table 5. It can be observed that maximum theoretical exergetic efficiency of overall drying system was $88.56 \%$ which exceeded more than $90 \%$ under favorable operating conditions, if applied.

Table 5. Outcomes of exergy analysis under theoretical and optimized (used for unavoidable irreversibilities) operating conditions.

\begin{tabular}{|c|c|c|c|c|c|c|c|c|c|}
\hline & \multirow{2}{*}{ Combination } & \multicolumn{4}{|c|}{ Theoretical Operating Conditions } & \multicolumn{4}{|c|}{ Favourable Operating Conditions } \\
\hline & & $E_{x i}(k W)$ & $E_{x o}(k W)$ & $E_{x d}(k W)$ & $\eta_{\text {ex }}(\%)$ & $E_{x f}(k W)$ & $E_{x p}(k W)$ & $E_{x d}(k W)$ & $\eta_{\text {ex }}(\%)$ \\
\hline \multirow{3}{*}{ Case-I } & Drying chamber & 15.23 & 13.15 & 2.08 & 86.34 & 14.97 & 13.46 & 1.51 & 89.91 \\
\hline & Gas heating & 16.44 & 14.9 & 1.54 & 36.57 & 16.98 & 15.48 & 1.50 & 35.63 \\
\hline & Overall system & 31.67 & 28.05 & 3.62 & 88.56 & 31.95 & 28.94 & 3.01 & 90.58 \\
\hline \multirow{3}{*}{ Case-II } & Drying chamber & 14.25 & 12.35 & 1.90 & 86.67 & 14.53 & 12.98 & 1.55 & 89.33 \\
\hline & Dual heating & 16.48 & 13.96 & 2.52 & 48.37 & 16.43 & 14.50 & 1.93 & 37.04 \\
\hline & Overall System & 30.73 & 26.31 & 4.42 & 85.62 & 30.96 & 27.48 & 3.48 & 88.76 \\
\hline \multirow{3}{*}{ Case-III } & Drying chamber & 12.85 & 11.09 & 1.76 & 86.30 & 14.31 & 12.80 & 1.51 & 89.45 \\
\hline & Solar heating & 14.85 & 12.56 & 2.29 & 27.89 & 15.94 & 13.90 & 2.04 & 24.85 \\
\hline & Overall system & 27.70 & 23.65 & 4.05 & 85.38 & 30.25 & 26.70 & 3.55 & 88.26 \\
\hline
\end{tabular}

After that rates of exergy destruction were split into endogenous and exogenous quantities. For endogenous part, the component being considered operated with same efficiency as in actual system while other components supposed to work ideally (as conditions mentioned in Table 3). Using equations mentioned in Table 2, the calculated rates of exergy destruction (EN, EX, AV and UN) were combined to calculate further four parts (AV-EN, AV-EX, UNEN and UN-EX) and results are summarized in Table 6.

Table 6. Advanced exergy analysis for the solar hybrid dehydrator.

\begin{tabular}{|c|c|c|c|c|c|c|c|c|c|c|}
\hline & \multirow{2}{*}{ Combination } & \multirow{2}{*}{$\begin{array}{c}\eta_{\text {ex Modified }} \\
(\%)\end{array}$} & \multirow{2}{*}{$\begin{array}{l}E x_{d k}^{E N} \\
\mathbf{( k W )}\end{array}$} & \multirow{2}{*}{$\begin{array}{l}E x_{d k}^{E X} \\
(\mathbf{k W})\end{array}$} & \multirow{2}{*}{$\begin{array}{c}E x_{d k}^{U N} \\
(\mathbf{k W})\end{array}$} & \multirow{2}{*}{$\begin{array}{l}E x_{d k}^{A V} \\
(\mathbf{k W})\end{array}$} & \multicolumn{2}{|c|}{$\begin{array}{l}E x_{d k}^{U N} \\
(\mathbf{K W})\end{array}$} & \multicolumn{2}{|c|}{$\begin{array}{l}E x_{d k}^{A V} \\
(\mathbf{K W})\end{array}$} \\
\hline & & & & & & & $\begin{array}{l}E x_{d k}^{U N E N} \\
(\mathbf{K W})\end{array}$ & $\begin{array}{l}E x_{d k}^{U N E X} \\
(\mathbf{K W})\end{array}$ & $\begin{array}{c}E x_{d k}^{A V E N} \\
(\mathbf{K W})\end{array}$ & $\begin{array}{c}E x_{d k}^{A V E X} \\
(\mathbf{K W})\end{array}$ \\
\hline \multirow{3}{*}{ Case-I } & Drying chamber & 95.45 & 2.11 & 0.26 & 1.49 & 0.88 & 1.47 & 0.022 & 0.63 & 0.24 \\
\hline & Heating chamber (Gas) & 99.23 & 1.56 & 0.43 & 1.46 & 0.53 & 1.44 & 0.019 & 0.11 & 0.42 \\
\hline & Overall system & 97.41 & 3.67 & 0.70 & 2.95 & 1.42 & 2.91 & 0.042 & 0.75 & 0.66 \\
\hline \multirow{3}{*}{ Case-II } & Drying chamber & 96.61 & 1.91 & 0.22 & 1.48 & 0.65 & 1.47 & 0.008 & 0.44 & 0.21 \\
\hline & Heating chamber (Dual) & 95.46 & 2.52 & 0.31 & 1.86 & 0.97 & 1.86 & 0.001 & 0.66 & 0.31 \\
\hline & Overall System & 95.99 & 4.43 & 0.53 & 3.34 & 1.62 & 3.33 & 0.010 & 1.10 & 0.52 \\
\hline \multirow{3}{*}{ Case-III } & Drying chamber & 96.08 & 1.76 & 0.09 & 1.31 & 0.54 & 1.31 & 0.001 & 0.45 & 0.09 \\
\hline & Heating chamber (Solar) & 96.26 & 2.34 & 0.46 & 1.89 & 0.91 & 1.84 & 0.043 & 0.50 & 0.41 \\
\hline & Overall system & 96.16 & 4.10 & 0.55 & 3.18 & 1.47 & 3.14 & 0.040 & 0.96 & 0.51 \\
\hline
\end{tabular}


It can be observed from the calculated date that the endogenous exergy destructions for the overall drying system were significant possessing $83.79 \%, 89.31 \%$ and $88.17 \%$ of total exergy destruction rates for the case I, case II and case III respectively. For an overall system, comparing system components, it is noticed that major portion of system endogenous exergy destruction rate was added by heating component especially in case I and case II with a maximum of $2.52 \mathrm{~kW}$ for dual heating (case-II). On the other side, exogenous energy destruction rates of respective components and overall systems were found lower. Keeping in view the need/desire of more rate of energy utilization in the drying chamber and energy addition in the heating part, these values show that the irreversibilities could not be decreased independently (component wise) but by overall improvement of the system (interconnection mode). The information extracted could be narrated that individually system components worked well but actually their working in interaction mode need improvement from design point of view. It means under full load capacity, heating component remain unable to meet the heating demand of drying process especially at initial phases of drying time (could be due to less effective heat exchanger or undersized solar collector), so rate of exegy destruction reduced in the drying chamber. Secondly, irreversibilities could also be reduced by optimizing process conditions like drying temperature, airflow rate, relative humidity, and percentage air recirculation

Further considering the characteristics of food drying curves, the rate of exergy destruction is higher (more energy utilization rate) at the start of drying process due to high removal of food moisture but it reduced as the process continued due to tightly bounded hygroscopic moisture causing less rate of exergy loss. So rate of exergy destruction varies throughout a drying process therefore rate of exergy inflow to a system component or an overall system cannot remain constant which is normal in practice i.e., drying temperature inside the drying chamber is maintained even during the ending phase of drying process when rate of energy utilization decreased. It causes wastages of exergy which needs to be avoided. It can be done by lowing the drying air temperature at the final stages of drying process and recirculation of warm air. The unavoidable exergy destruction rates are the amount of exergy which need to complete the drying process while rates of avoidable exergy loss are the potential to save exergy during the entire drying process. Secondly, considering the technical aspect of components, the avoidable exergy destruction rates represent the exergy unnecessarily being dealt. It can be noted that $32.42 \%, 32.66 \%$, and $31.61 \%$ of total exergy destruction rates were avoidable in case I, case II and case III respectively in the overall system. Although rates of avoidable exergy destruction are found less than unavoidable but in order to increase system efficiency, avoidable exergy destruction is always focused. Further to assess the percentage of avoidable exergy destruction due to components independently and in interconnected form, the parameters avoidable endogenous and exogenous were calculated. Out of the voidable rates of exergy destruction, 53\%, $68 \%, 65 \%$ were avoidable endogenous (AV-EN) in case I, case II and case III respectively as shown in Figure 5. It can be noted that in overall system, the modified exergy efficiency for heating chamber was almost same both in case II and case III while comparatively slightly higher in case I due to little less avoidable destruction rates $(0.53 \mathrm{~kW})$ as shown in Table 6 . It shows that gas burner itself worked well. The main factor of higher avoidable destruction rates in other two cases (case I and case II) were due to less efficient heat exchanger or undersized solar collector as disused earlier. 

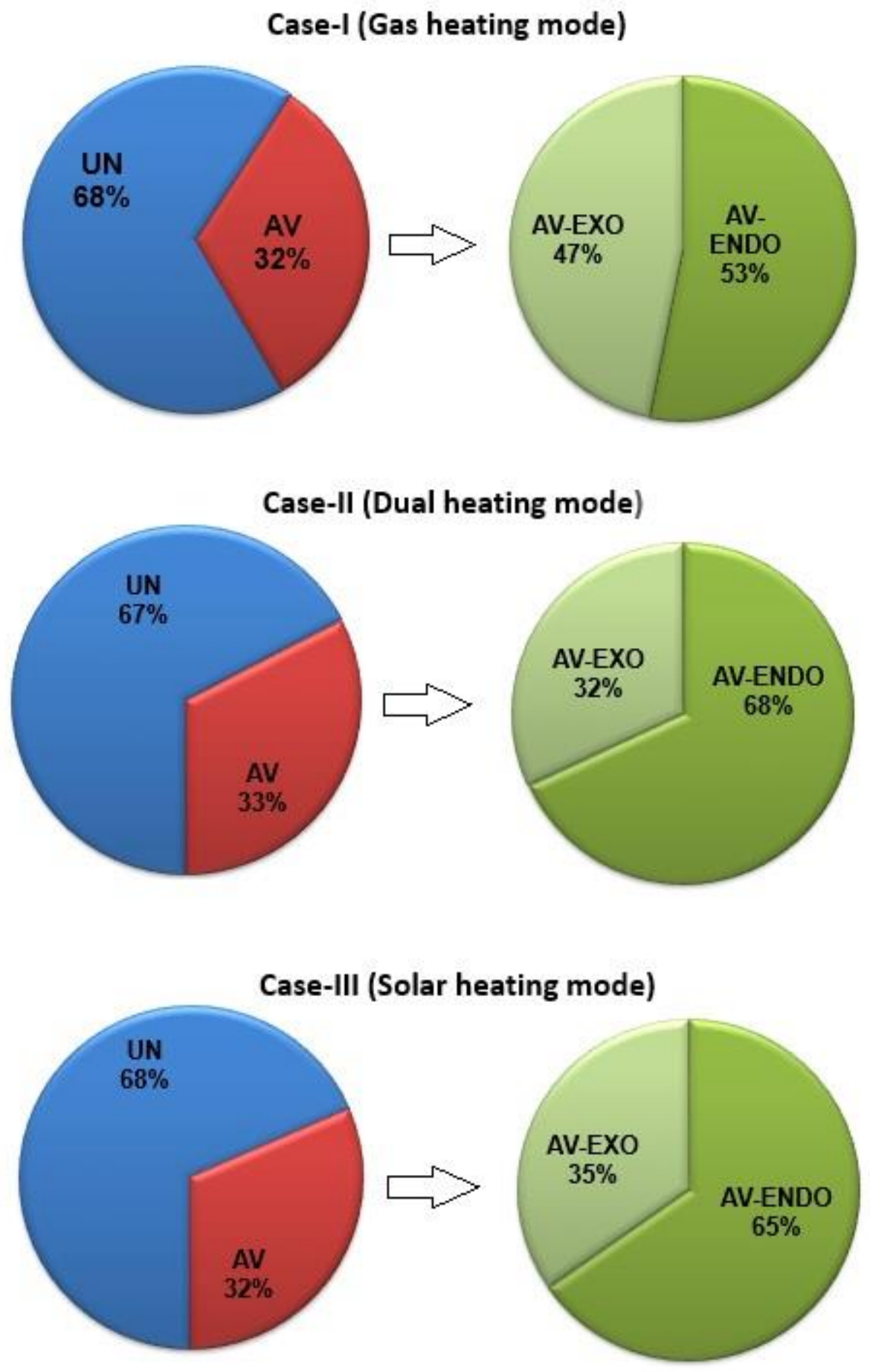

Figure 5. Percentage distribution of total exergy destruction into avoidable and unavoidable (left column) and division of avoidable exergy part into its endogenous and exogenous portions (right column) for the drying process of overall system under three different heating modes.

This show that higher values of inefficiencies in heating sources could be reduced technologically through focusing on the operating conditions of the heating sources. It can be noted that dual heating mode (case II) possessed higher percentage of AV-EN which can be reduced by optimizing its auto operational control. Further, it has lower modified exergy efficiency (Table 6) and more percentage (32.66\%) of total exergy destruction rates as avoidable comparative to other two cases. Moreover, it can be noted that although avoidable rate of exergy destruction were lower than unavoidable for the components in all cases. However, major part of the total avoidable destruction rates were found as 
AV-EN in all cases (Figure 5). So improvements may be done by focusing on components individually while the improvement in overall system (components interaction) cannot not be ignored as well. Figure 5 shows that for the overall system, out of total voidable rates of exergy destruction, $47 \%(0.66 \mathrm{~kW}), 32 \%(0.52 \mathrm{~kW}), 35 \%(0.51 \mathrm{~kW})$ were avoidable exogenous (AV-EX) in case I, case II and case III respectively. For case I, out of major part of total $0.66 \mathrm{~kW}$ avoidable exogenous, $0.42 \mathrm{~kW}$ contributed by the heating chamber which show that heating efficiency of gas burner depends on the heat exchanger which ultimately effect drying efficiency in the drying chamber (receives heated air from heat exchanger). Similar findings are found for the other two cases especially in case III, the heating efficiency of heat exchanger depends upon the flow rate and water temperature coming from the solar collector (whose efficiency depends on solar irradiation).

\section{Conclusions}

In the current study an advanced exergy analysis of a solar hybrid food dryer was performed based on the results obtained through conventional exergy analysis to evaluate the system components interactions and to assess the actual improvement potential both for the system components and overall system. Conventional exergy analysis revealed that drying chamber possessed lower improvement potential rate (IP) than heating components. While comparing heating sources, the highest improvement potential rate $(1.85 \mathrm{~kW})$ was found for solar heating (case III) with lowest exergy efficiency (34.10\%). Advanced exergy analysis showed that while working in interaction mode, there is need to improve design of system components as the endogenous part of exergy destruction rates were found more than exogenous part. For an overall system, comparing system components, major portion of system endogenous exergy destruction rate was added by heating component in all cases of heating modes. So improvement may be done by optimizing the size and operational conditions for solar collector, heat exchanger and gas burner for the overall improvement in the system. Efficiency of solar evacuated tube collector depends on the solar irradiance so it is recommended to optimize under certain climatic conditions followed by flow regulation of working medium (water glycol solution) to optimize retention time for the exchange of heat in the heat exchanger. Moreover, use of humidity controller to decide the correct time of air recirculation from drying chamber can not only help to increase the heating efficiency of heat exchanger but also drying efficiency. For future study, the effect of drying air temperature, airflow rate, product loading density and size on exergy efficiencies of the overall system can be investigated.

The study possess industrial applications for large drying processes as the information obtained through conducting an advanced exergetic analysis is valuable to understand the energy flow and distribution in a system and to develop plans for improvement.

Author Contributions: Conceptualization, W.A. and A.M.; data curation, A.M. and J.-T.K.; formal analysis, F.M.; funding acquisition, W.A. and J.-T.K.; investigation, M.A.R. and S.N.H.; methodology, M.A.R. and F.A.; project administration, W.A.; resources, W.A.; software, F.A. and F.M.; supervision, W.A. and A.M.; validation, W.A. and M.I.H.; visualization, F.M. and S.N.H.; writing-original draft, W.A. and M.A.R.; writing-review \& editing, F.A. and M.I.H. All authors have read and agreed to the published version of the manuscript.

Funding: This work is published with the support of National Research Foundation of Korea (NRF) grant funded by the Korea government (MSIT) (NRF-2021R1A2C2092760).

Institutional Review Board Statement: Not applicable.

Informed Consent Statement: Not applicable.

Data Availability Statement: Not applicable.

Acknowledgments: This work is a part of research project No. TDF-061 funded by Higher Education Commission (HEC) of Pakistan under its Technology Development Fund (TDF).

Conflicts of Interest: The authors declare that there is no conflict of interest. 


\section{Nomenclature}

$\begin{array}{ll}\text { Symbol } & \\ \mathrm{T} & \text { temperature }\left({ }^{\circ} \mathrm{C}\right) \\ \mathrm{Ex} & \text { exergy }(\mathrm{kJ} / \mathrm{kg}) \\ \mathrm{m} & \text { mass flow rate }(\mathrm{kg} / \mathrm{s}) \\ \mathrm{Cp} & \text { specific heat capacity }(\mathrm{kJ} / \mathrm{kg} . \mathrm{K}) \\ \Delta \mathrm{t} & \text { difference in temeprature } \\ \mathrm{IP} & \text { improvement potential rate }\left(\mathrm{kJs}^{-1}\right) \\ \mathrm{f} & \text { exergetic factor }(\%) \\ \mathrm{RI} & \text { relative irreversibility }(\%) \\ \text { SI } & \text { sustainability index }(\%) \\ \eta & \text { efficiency } \\ \mathrm{P} & \text { work rate or power }(\mathrm{kJ} / \mathrm{s} \text { or Kw) } \\ \text { ETC } & \text { evacuated tube collector } \\ \text { Superscripts } & \\ \text { AV } & \text { avoidable } \\ \text { UN } & \text { unavoidable } \\ \text { EN } & \text { endogenous } \\ \text { EX } & \text { exogenous } \\ \text { Real } & \text { actual/emperical } \\ \text { Subscripts } & \\ \text { i } & \text { inlet position } \\ \text { o } & \text { outlet position } \\ \text { da } & \text { drying air } \\ \text { dci } & \text { drying chamber inlet } \\ \text { dci } & \text { drying chamber outlet } \\ \text { xd } & \text { exergy destruction } \\ \text { xi } & \text { exergy inflow } \\ \text { xo } & \text { exergy outflow } \\ \mathrm{k} & \mathrm{k}^{\text {th }} \text { component } \\ & \end{array}$

\section{References}

1. Sagar, V.R.; Kumar, P.S. Recent advances in drying and dehydration of fruits and vegetables: A review. J. Food Sci. Technol. 2010, 47, 15-26. [CrossRef] [PubMed]

2. Amjad, W.; Waseem, M.; Munir, A.; Ghafoor, A.; Asghar, F.; Gilani, G.A. Solar Assisted Dehydrator for Decentralized Controlled and Homogeneous Multi-Product Drying. J. Sol. Energy Eng. 2020, 143. [CrossRef]

3. Jia, C.; Wang, L.; Guo, W.; Liu, C. Effect of swing temperature and alternating airflow on drying uniformity in deep-bed wheat drying. Appl. Therm. Eng. 2016, 106, 774-783. [CrossRef]

4. Yuan, Y.P.; Sun, D.W. Combined hot-air and microwave-vaccum drying for improving drying uniformity of mango slices based on hyperspecial imaging visualization of moisture content distribution. Biosyst. Eng. 2017, 156, 108-119.

5. Kong, D.; Wang, Y.; Li, M.; Keovisar, V.; Huang, M.; Yu, Q. Experimental study of solar photovoltaic/thermal (PV/T) air collector drying performance. Sol. Energy 2020, 208, 978-989. [CrossRef]

6. Sohani, A.; Shahverdian, M.H.; Sayyaadi, H.; Samiezadeh, S.; Doranehgard, M.H.; Nizetic, S.; Karimi, N. Selecting the best nanofluid type for A photovoltaic thermal (PV/T) system based on reliability, efficiency, energy, economic, and environmental criteria. J. Taiwan Inst. Chem. Eng. 2021, 124, 351-358. [CrossRef]

7. Sogut, Z.; Ilten, N.; Oktay, Z. Energetic and exergetic performance evaluation of the quadruple-effect evaporator unit in tomato paste production. Energy 2010, 35, 3821-3826. [CrossRef]

8. Aghbashlo, M.; Mobli, H.; Rafiee, S.; Madadlou, A. A review on exergy analysis of drying processes and systems. Renew. Sustain. Energy Rev. 2013, 22, 1-22. [CrossRef]

9. Şevik, S.; Aktaş, M.; Dolgun, E.C.; Arslan, E.; Tuncer, A.D. Performance analysis of solar and solar-infrared dryer of mint and apple slices using energy-exergy methodology. Sol. Energy 2019, 180, 537-549. [CrossRef]

10. Aziz, A.; Rehman, S.U.; Rehman, S.U. Exergy analysis of solar cabinet dryer and evaluate the performance enhancement of solar cabinet dryer by addition of solar reflector. Int. J. Renewable Energy Res. 2016, 6, 2016.

11. Aviara, N.A.; Onuoha, L.N.; Falola, O.E.; Igbeka, J.C. Energy and exergy analyses of native cassava starch drying in a tray dryer. Energy 2014, 73, 809-817. [CrossRef]

12. Sami, S.; Etesami, N.; Rahimi, A. Energy and exergy analysis of an indirect solar cabinet dryer based on mathematical modeling results. Energy 2011, 36, 2847-2855. [CrossRef] 
13. Chowdhury, M.; Bala, B.; Haque, M. Energy and exergy analysis of the solar drying of jackfruit leather. Biosyst. Eng. 2011, 110, 222-229. [CrossRef]

14. Aghbashlo, M.; Kianmehr, M.H.; Arabhosseini, A. Energy and Exergy Analyses of Thin-Layer Drying of Potato Slices in a Semi-Industrial Continuous Band Dryer. Dry. Technol. 2008, 26, 1501-1508. [CrossRef]

15. Rabha, D.K.; Muthukumar, P.; Somayaji, C. Energy and exergy analyses of the solar drying processes of ghost chilli pepper and ginger. Renew. Energy 2017, 105, 764-773. [CrossRef]

16. Sundari, A.U.; Neelamegam, P.; Subramanian, C.V. An Experimental Study and Analysis on Solar Drying of Bitter Gourd Using an Evacuated Tube Air Collector in Thanjavur, Tamil Nadu, India. Conf. Pap. Energy 2013, 2013, 1-4. [CrossRef]

17. Amjad, W.; Gilani, G.A.; Munir, A.; Asghar, F.; Ali, A.; Waseem, M. Energetic and exergetic thermal analysis of an inline-airflow solar hybrid dryer. Appl. Therm. Eng. 2019, 166, 114632. [CrossRef]

18. Lamnatou, C.; Papanicolaou, E.; Belessiotis, V.; Kyriakis, N. Experimental investigation and thermodynamic performance analysis of a solar dryer using an evacuated-tube air collector. Appl. Energy 2012, 94, 232-243. [CrossRef]

19. Tsatsaronis, G.; Morosuk, T. Advanced exergetic analysis of a novel system for generating electricity and vaporizing liquefied natural gas. Energy 2010, 35, 820-829. [CrossRef]

20. Erbay, Z.; Hepbasli, A. Advanced Exergy Analysis of a Heat Pump Drying System Used in Food Drying. Dry. Technol. 2013, 31, 802-810. [CrossRef]

21. Erbay, Z.; Hepbasli, A. Application of conventional and advanced exergy analyses to evaluate the performance of a ground-source heat pump (GSHP) dryer used in food drying. Energy Convers. Manag. 2014, 78, 499-507. [CrossRef]

22. Gungor, A.; Erbay, Z.; Hepbasli, A.; Gunerhan, H. Splitting the exergy destruction into avoidable and unavoidable parts of a gas engine heat pump (GEHP) for food drying processes based on experimental values. Energy Convers. Manag. 2013, 73, 309-316. [CrossRef]

23. Tinoco-Caicedo, D.; Lozano-Medina, A.; Blanco-Marigorta, A. Conventional and Advanced Exergy and Exergoeconomic Analysis of a Spray Drying System: A Case Study of an Instant Coffee Factory in Ecuador. Energies 2020, 13, 5622. [CrossRef]

24. Rosen, M.A.; Dincer, I.; Kanoglu, M. Role of exergy in increasing efficiency and sustainability and reducing environmental impact. Energy Policy 2008, 36, 128-137. [CrossRef]

25. Kelly, S. Energy Systems Improvement Based on Endogenous and Exogenous Exergy Destruction. Ph.D. Thesis, Institutfür Energie-Technik, Technische Universtät Berlin, Berlin, Germany, 2008.

26. Almutairi, A.; Pilidis, P.; Al-Mutawa, N. Energetic and Exergetic Analysis of Combined Cycle Power Plant: Part-1 Operation and Performance. Energies 2015, 8, 14118-14135. [CrossRef] 